\title{
Trade, Patents and International Technology Diffusion
}

\author{
BIN XU* \& ERIC P. CHIANG** \\ * China Europe International Business School and University of Florida \\ **Florida Atlantic University
}

\begin{abstract}
This paper investigates international technology diffusion through trade and patenting in a sample of 48 countries for the period 1980-2000. We divide the sample in three income groups to detect different patterns of technology absorption. Our results show that rich countries benefit from domestic technology and foreign technology embodied in imported capital goods, middle-income countries enjoy technology spillovers from foreign patents and imported capital goods, and poor countries benefit mainly from foreign patents. We find that government policies on intellectual property rights protection and trade openness have large effects on foreign technology spillovers in middle- and low-income countries.
\end{abstract}

KEY WORDS: International technology diffusion, trade, patents, productivity

\section{Introduction}

International technology diffusion is a widely studied topic in the economic literature. ${ }^{1}$ While much disagreement remains, especially on measurement, researchers do seem to agree on two points. First, most countries have benefited from technological inventions of foreign countries. A strong argument for this is that the majority of the world's R\&D is performed in a handful of industrial countries, yet productivity gains are widespread over the world. Second, international technology diffusion is not frictionless and its effect on productivity of the recipient country is not automatic. There are natural and man-made barriers that need to be overcome, and learning and absorption that need to occur.

In this paper we start from these two agreed points and take a step further. First, we ask if countries at different development stages benefit from different sources of foreign technology. ${ }^{2}$ Second, if they do, we explore the reasons for it, particularly those associated with policy variables. To 
implement our investigation, we construct a sample of 48 countries for the period 1980 to 2000, and divide the sample in three groups according to real GDP per capita. This classification has an advantage over the conventional classification of developing countries versus developed countries, which groups Singapore with Zambia while grouping New Zealand with the United States, despite the fact that Singapore and New Zealand share more similarity in economic structure.

We model international technology diffusion from three sources. Following Coe and Helpman (1995) and Coe et al. (1997), we consider international trade as a carrier of foreign technology embodied in capital goods. Following Eaton and Kortum (1996), we consider international patenting as another technology diffusion channel. In addition, we follow Benhabib and Spiegel (1994) to use the Nelson-Phelps (1966) specification which postulates that technology diffuses in disembodied form from technology-leading countries to technology-following countries at a rate that increases with the technology gap between them and with the human capital level of the technology-following countries.

There are several advantages of including the aforementioned three sources of international technology spillovers in one regression. First, it allows us to investigate the relative importance of these sources to countries at different development stages. Second, it provides a better estimation of the significance of a particular technology spillover channel. ${ }^{3}$ Third, it allows a richer analysis of policy implications. In our study, we are able to separate the productivity effect of trade openness through increasing imported capital goods and the productivity effect of trade openness through encouraging foreign patenting.

We organize the paper as follows. In Section 2 we describe some features of the data. In Section 3 we discuss the theoretical framework for determination of productivity growth and determination of foreign patent inflow. In Section 4 we report results from productivity regressions and foreign patent regressions, and use these estimates to assess the role of intellectual property rights protection and trade openness. In Section 5 we summarize our results and provide concluding remarks. An appendix contains information on data sources and variable construction.

\section{Data}

Our study uses a sample of 48 countries for the period 1980 to 2000 . In this section we discuss some features of the data. Details of the data are in the appendix.

Patent data are important to our study. The World Intellectual Property Organization (WIPO) collects patent data from member countries. There are two data series of patent counts. First is the number of patent applications filed by residents. We use this data to define variable $P D$, which we will refer to as domestic patents. Figure 1 shows that the number of 
domestic patents is highly correlated with domestic R\&D expenditure. This high correlation may not be surprising if we view R\&D expenditure as input and patents as output in a knowledge creation process. The domestic patent data are useful for our study because they are available for both developing countries (LDCs) and developed countries (DCs), while R\&D data are available only for DCs. ${ }^{4}$ A number of studies (e.g. Coe et al., 1997) ignore domestic technology activity in developing countries in their estimation of productivity effects on the grounds that domestic $R \& D$ is small in developing countries and R\&D data for these countries are not available. The domestic patent data allows us to test if the productivity effect of domestic technology activity is indeed unimportant in developing countries.

The second data series of patent counts is the number of patent applications filed by non-residents. We use this data to define variable $P F$, which we will refer to as foreign patents. Figure 2 plots the number of foreign patents per thousand workers (in logarithms) against real GDP per capita. The correlation is positive for about two thirds of the countries, suggesting that the level of economic development is an important determinant of foreign patent inflow in these countries. There are other determinants of foreign patent inflow including intellectual property rights (IPR) protection and trade openness. We will use regression analysis to examine this issue more formally in Section $4 .^{5}$

One hypothesis of this paper is that countries at different development stages may exhibit different patterns of technology absorption. To investigate this hypothesis, we divide the sample in three groups according

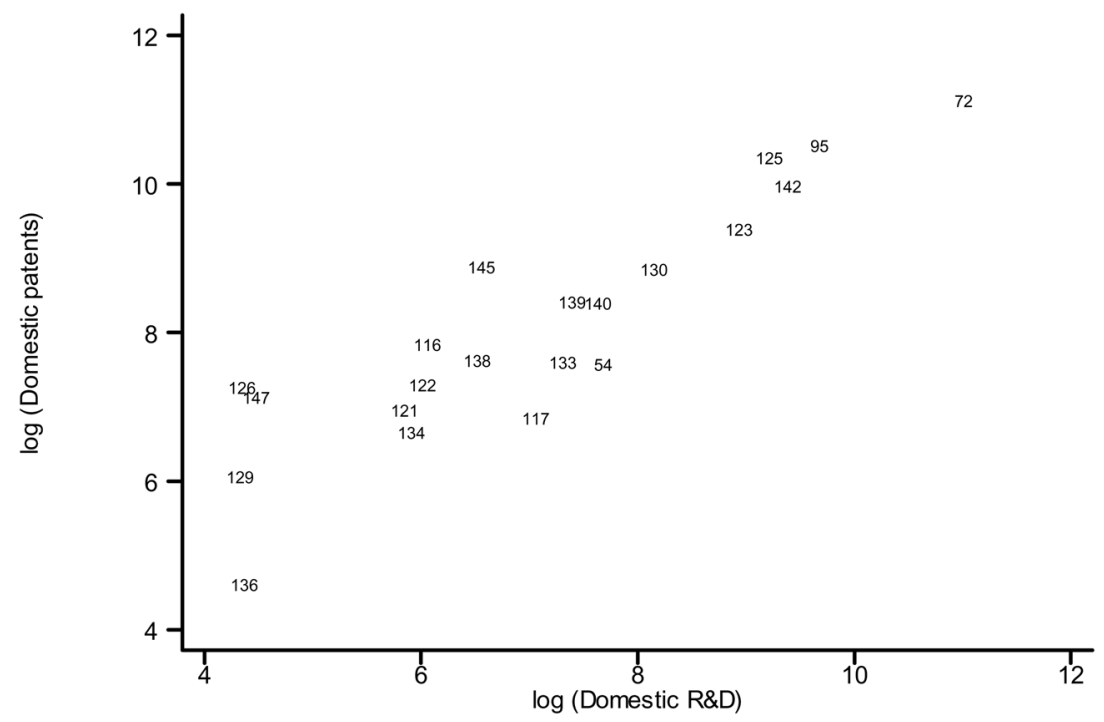

Figure 1. Domestic patents and R\&D, 1980 


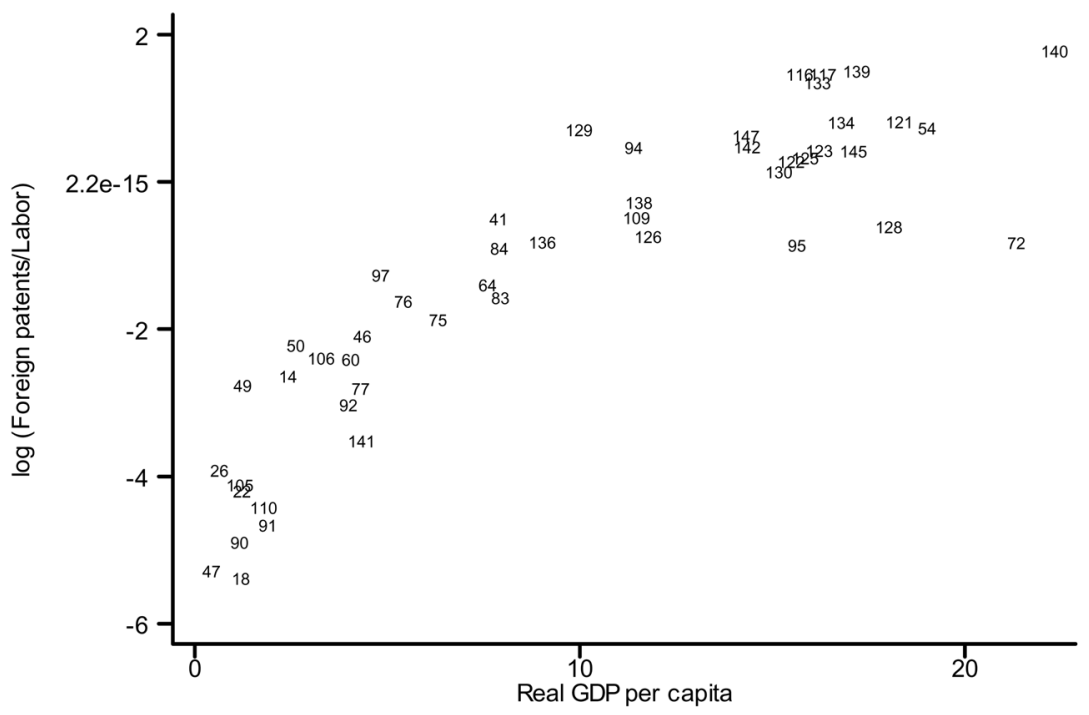

Figure 2. Foreign patents and development level, 1980

to real GDP per capita $(R G D P L)$. This variable, taken from Penn World Table 6.1, is GDP per capita in 1996 international prices. In Table 1, countries are ranked in ascending order of $R G D P L$ (value averaged over the sample period). The first 16 countries have $R G D P L$ below $\$ 5500$; we place them in a low-income group. The next 15 countries have $R G D P L$ between $\$ 5500$ and $\$ 17,000$; we place them in a middle-income group. The last 17 countries have $R G D P L$ above $\$ 17,000$; they belong to a high-income group. ${ }^{6}$ All low-income countries are LDCs and all high-income countries are DCs. The middle-income group contains ten LDCs and five DCs.

Table 1 provides summary statistics of several key variables for each country in our sample. Variable TFPG is the average annual growth rate of total factor productivity (TFP). Over the sample period, 42 countries experienced positive TFP growth (the highest being Ireland at $2.78 \%$ per year) and six countries experienced negative TFP growth (the lowest being Colombia at $-1.11 \%$ per year). Variable $H$ is the total education attainment in population over age $15^{7}$ The value of $H$ varies considerably across countries, with 2.50 for Uganda (lowest) and 11.76 for the US (highest). Variable $I P R$ is an index of patent rights constructed by Ginarte and Park (1997). The value of the index ranges from zero (weakest) to five (strongest). In our sample, Indonesia has the lowest value of IPR at 0.64 and the US has the highest value of $I P R$ at 4.55 .

Table 2 provides summary statistics of variables used in our regression analysis. There are four patent variables. $P F L$ is foreign patent flow per thousand workers, $P D L$ is domestic patent flow per thousand workers, $S F$ is 
foreign patent stock, and $S D$ is domestic patent stock; stocks are constructed from flows using the perpetual inventory method (see the Appendix). On average the number of foreign patents is larger than the number of domestic patents for all income groups. Domestic R\&D stock $(S D)$ is constructed from data on $\mathrm{R} \& \mathrm{D}$ expenditure $(R D)$, which is available only for developed countries. Variable $S M$ is an import share weighted sum of R\&D stocks of trade partners, a variable used by Coe-Helpman (1995) to measure R\&D spillovers embodied in imports. Previous studies have found that trade-embodying foreign technology diffuses mainly through capital goods, so we use shares of capital goods imports as the weight in the construction of $S M .^{8}$ Variable $M$ is the GDP share of imported capital goods from five major industrial countries (US, UK, Japan, Germany, and France). ${ }^{9}$ Variable GAP is the ratio of US TFP to the sample country's TFP. Variable TRADE is total trade (imports plus exports) in 1996 international prices.

\section{Framework}

In this section we discuss the regression specification that we use to estimate technology spillovers through international trade and foreign patenting, and also the regression specification for estimating the determinants of foreign patent inflow.

\subsection{Productivity and Knowledge Stocks}

We start with the Coe-Helpman (1995) approach that has been widely used in the recent literature. Consider an aggregate production function for country $i$ at time $t, Y_{i t}=F_{i t}\left(L_{i t}, K_{i t}, S_{i t}\right)$, where $Y, L, K$ and $S$ denote GDP, labour, physical capital, and knowledge capital, respectively. Assuming a Cobb-Douglas functional form and applying logarithms, we have log $T F P_{i t}=\alpha_{S} \log S_{i t}$, where $\log T F P_{i t} \equiv \log Y_{i t}-\alpha_{L} \log L_{i t}-\alpha_{K} \log K_{i t}$. Next consider knowledge capital $(S)$ to have a domestic component $(S D)$ and a foreign component $(S M)$ that complement each other, $\log S_{i t}=\alpha_{D} \log S D_{i t}$ $+\alpha_{M} \log S M_{i t}$. In Coe and Helpman's (1995) study of industrial countries, $S D$ is domestic R\&D stock, and $S M$ is foreign R\&D embodied in imported goods. In Coe et al.'s (1997) study of developing countries, SD is omitted due to lack of R\&D data, and $S M$ is foreign R\&D embodied in capital goods imported from industrial countries.

Our extension includes foreign patent inflow as another channel for international technology diffusion. We assume that $\log S_{i t}=\alpha_{D} \log S D_{i t}+$ $\alpha_{F} \log S F_{i t}+\alpha_{M} \log S M_{i t}$, where $S F$ is the stock of patent applications from foreigners, $S M$ is foreign R\&D embodied in capital goods imported from five major technology-innovating countries, and $S D$ is domestic $R \& D$ stock. For countries with no available data on domestic R\&D stock, we use the stock of domestic patent applications as a proxy. ${ }^{10}$ 
Table 1. Summary statistics by country, 1980-2000

\begin{tabular}{|c|c|c|c|c|c|c|c|c|}
\hline Group & $I d$ & Country & $R G D P L$ & GTFP & $P F$ & $P D$ & $H$ & $I P R$ \\
\hline $\mathrm{L}$ & 26 & MALAWI & 0.66 & 2.57 & 20.26 & 0.002 & 2.85 & 3.18 \\
\hline $\mathrm{L}$ & 47 & UGANDA & 0.73 & 1.12 & 0.05 & 0.001 & 2.50 & 2.65 \\
\hline $\mathrm{L}$ & 49 & ZAMBIA & 1.02 & 0.58 & 0.10 & 0.004 & 4.48 & 3.52 \\
\hline $\mathrm{L}$ & 18 & GHANA & 1.19 & 0.87 & 0.04 & 0.002 & 3.64 & 2.71 \\
\hline $\mathrm{L}$ & 22 & KENYA & 1.25 & 0.10 & 0.09 & 0.01 & 3.63 & 2.67 \\
\hline $\mathrm{L}$ & 105 & PAKISTAN & 1.67 & 1.94 & 0.60 & 0.02 & 2.89 & 1.99 \\
\hline $\mathrm{L}$ & 90 & INDIA & 1.71 & 2.30 & 7.82 & 1.19 & 4.01 & 1.59 \\
\hline $\mathrm{L}$ & 110 & SRI LANKA & 2.56 & 1.04 & 11.39 & 0.04 & 6.11 & 3.06 \\
\hline $\mathrm{L}$ & 50 & ZIMBABWE & 2.72 & 0.30 & 0.18 & 0.04 & 3.66 & 2.93 \\
\hline $\mathrm{L}$ & 91 & INDONESIA & 2.89 & 0.04 & 7.86 & 0.05 & 4.20 & 0.64 \\
\hline $\mathrm{L}$ & 106 & PHILIPPINES & 3.08 & -0.39 & 2.11 & 0.12 & 7.14 & 2.67 \\
\hline $\mathrm{L}$ & 14 & EGYPT & 3.23 & 1.76 & 0.70 & 0.27 & 3.99 & 2.01 \\
\hline $\mathrm{L}$ & 60 & GUATEMALA & 3.72 & -0.14 & 0.12 & 0.02 & 3.01 & 1.03 \\
\hline $\mathrm{L}$ & 92 & IRAN & 4.51 & 1.81 & 0.21 & 0.24 & 3.88 & 2.39 \\
\hline $\mathrm{L}$ & 77 & COLOMBIA & 4.90 & -1.11 & 0.81 & 0.08 & 4.73 & 1.57 \\
\hline $\mathrm{L}$ & 46 & TUNISIA & 5.19 & 1.37 & 0.15 & 0.03 & 3.80 & 1.92 \\
\hline M & 141 & TURKEY & 5.63 & 0.68 & 9.91 & 0.19 & 4.17 & 1.85 \\
\hline M & 75 & BRAZIL & 6.42 & 0.44 & 17.99 & 2.07 & 3.86 & 2.19 \\
\hline M & 76 & CHILE & 6.86 & 0.56 & 1.17 & 0.16 & 6.91 & 2.61 \\
\hline M & 84 & VENEZUELA & 7.09 & -0.37 & 1.63 & 0.25 & 5.88 & 1.79 \\
\hline M & 64 & MEXICO & 7.59 & -0.29 & 15.39 & 0.61 & 5.90 & 1.87 \\
\hline $\mathrm{M}$ & 41 & SOUTH AFRICA & 7.65 & 0.59 & 10.27 & 4.14 & 5.34 & 3.59 \\
\hline M & 83 & URUGUAY & 8.03 & 0.25 & 0.22 & 0.04 & 6.98 & 2.38 \\
\hline M & 97 & KOREA & 10.01 & 2.57 & 28.00 & 20.38 & 9.34 & 3.78 \\
\hline M & 136 & PORTUGAL* & 11.82 & 1.06 & 41.69 & 0.09 & 4.53 & 2.27 \\
\hline M & 126 & GREECE* & 12.19 & 0.75 & 36.68 & 0.64 & 7.70 & 2.51 \\
\hline M & 94 & ISRAEL & 14.00 & 1.15 & 11.18 & 1.25 & 9.42 & 3.59 \\
\hline M & 138 & SPAIN* & 14.06 & 0.88 & 55.47 & 2.28 & 6.31 & 3.59 \\
\hline M & 129 & IRELAND* & 14.82 & 2.78 & 32.32 & 0.75 & 8.30 & 3.12 \\
\hline M & 147 & NEW ZEALAND* & 16.45 & 0.57 & 14.16 & 1.20 & 11.51 & 3.48 \\
\hline
\end{tabular}


Table 1. (continued)

\begin{tabular}{|c|c|c|c|c|c|c|c|c|}
\hline Group & $I d$ & Country & $R G D P L$ & GTFP & $P F$ & $P D$ & $H$ & $I P R$ \\
\hline M & 109 & SINGAPORE & 16.63 & 2.12 & 14.36 & 0.09 & 6.26 & 2.96 \\
\hline $\mathrm{H}$ & 142 & U.K.* & 17.89 & 1.28 & 80.79 & 24.25 & 8.75 & 3.60 \\
\hline $\mathrm{H}$ & 130 & ITALY* & 18.50 & 1.02 & 55.99 & 4.33 & 6.43 & 4.02 \\
\hline $\mathrm{H}$ & 122 & FINLAND* & 18.73 & 1.68 & 37.98 & 2.36 & 8.52 & 3.30 \\
\hline $\mathrm{H}$ & 123 & FRANCE* & 19.03 & 0.77 & 65.79 & 15.33 & 7.14 & 3.94 \\
\hline $\mathrm{H}$ & 125 & GERMANY* & 19.17 & -0.01 & 74.19 & 46.74 & 9.68 & 3.82 \\
\hline $\mathrm{H}$ & 133 & NETHERLANDS* & 19.21 & 0.91 & 53.53 & 3.80 & 8.72 & 4.28 \\
\hline $\mathrm{H}$ & 116 & AUSTRIA* & 19.22 & 1.08 & 57.11 & 2.57 & 7.73 & 4.14 \\
\hline $\mathrm{H}$ & 117 & BELGIUM* & 19.29 & 1.02 & 49.14 & 1.22 & 8.77 & 3.82 \\
\hline $\mathrm{H}$ & 139 & SWEDEN* & 19.88 & 1.06 & 59.21 & 5.57 & 10.09 & 3.80 \\
\hline $\mathrm{H}$ & 145 & AUSTRALIA* & 20.48 & 1.07 & 24.33 & 7.91 & 10.48 & 3.45 \\
\hline $\mathrm{H}$ & 128 & ICELAND* & 20.62 & 0.87 & 9.22 & 0.03 & 8.04 & 2.23 \\
\hline $\mathrm{H}$ & 95 & JAPAN* & 20.77 & 0.83 & 46.89 & 61.73 & 8.93 & 3.95 \\
\hline $\mathrm{H}$ & 134 & NORWAY* & 21.37 & 1.55 & 17.28 & 1.13 & 10.10 & 3.46 \\
\hline $\mathrm{H}$ & 121 & DENMARK* & 21.85 & 1.46 & 48.92 & 1.79 & 9.29 & 3.85 \\
\hline $\mathrm{H}$ & 54 & CANADA* & 21.97 & 0.45 & 37.79 & 3.05 & 10.96 & 3.01 \\
\hline $\mathrm{H}$ & 140 & SWITZERLAND* & 24.18 & 0.08 & 58.80 & 4.93 & 10.26 & 3.84 \\
\hline $\mathrm{H}$ & 72 & U.S.A.* & 26.24 & 0.79 & 84.11 & 94.80 & 11.76 & 4.55 \\
\hline
\end{tabular}

Note: Developed countries (DC) with an asterisk. 
Table 2. Summary statistics of variables, 1980-2000

\begin{tabular}{|c|c|c|c|c|c|}
\hline & & $A L L$ & $H I G H$ & $M I D D L E$ & $L O W$ \\
\hline$P F L$ & $\begin{array}{l}\text { Foreign patent } \\
\text { inflow per } \\
\text { thousand } \\
\text { workers }\end{array}$ & $5.29(20.24)$ & $50.65(42.37)$ & $19.36(33.10)$ & $3.28(11.80)$ \\
\hline$P D L$ & $\begin{array}{l}\text { Domestic } \\
\text { patent inflow } \\
\text { per thousand } \\
\text { workers }\end{array}$ & $0.36(0.47)$ & $16.56(27.51)$ & $2.34(8.22)$ & $0.15(0.32)$ \\
\hline$R D L$ & $\begin{array}{l}\text { Domestic } \\
\text { R\&D spending } \\
\text { per worker }\end{array}$ & NA & $0.54(0.26)$ & NA & NA \\
\hline$S F$ & $\begin{array}{l}\text { Foreign patent } \\
\text { stock } \\
\text { (thousand) }\end{array}$ & $92.15(13.13)$ & $205.30(146.30)$ & $53.82(83.16)$ & $7.85(21.42)$ \\
\hline$S D$ & $\begin{array}{l}\text { Domestic } \\
\text { patent stock } \\
\text { (thousand) }\end{array}$ & $41.13(101.18)$ & $91.16(142.33)$ & $10.25(23.34)$ & $1.17(2.21)$ \\
\hline$S R$ & $\begin{array}{l}\text { Domestic } \\
\text { R\&D stock } \\
\text { (billion) }\end{array}$ & NA & $156.95(354.05)$ & NA & NA \\
\hline$S M$ & $\begin{array}{l}\text { R\&D } \\
\text { embodied in } \\
\text { imported } \\
\text { capital goods }\end{array}$ & $581.10(321.67)$ & $521.38(307.03)$ & $686.97(342.73)$ & $542.42(289.03)$ \\
\hline$M$ & $\begin{array}{l}\text { Imported } \\
\text { capital goods } \\
\text { as a share of } \\
\text { GDP }(\%)\end{array}$ & $4.24(4.83)$ & $5.67(3.38)$ & $5.30(6.95)$ & $1.52(0.93)$ \\
\hline GTFP & $\begin{array}{l}\text { TFP growth } \\
\text { rate }(\%)\end{array}$ & $0.91(3.67)$ & $0.94(2.44)$ & $0.90(3.90)$ & 0.89 (4.46) \\
\hline$H$ & $\begin{array}{l}\text { Education } \\
\text { attainment in } \\
\text { population } \\
\text { over age } 15\end{array}$ & $6.72(2.70)$ & $9.16(1.45)$ & $6.83(2.15)$ & $4.03(1.31)$ \\
\hline GAP & TFP $_{\text {US }} /$ TFP & $2.03(1.23)$ & $1.28(0.14)$ & $1.59(0.26)$ & $3.25(1.47)$ \\
\hline$I P R$ & $\begin{array}{l}\text { Intellectual } \\
\text { property rights } \\
\text { protection } \\
\text { index }\end{array}$ & $2.94(0.95)$ & $3.71(0.58)$ & $2.77(0.80)$ & $2.28(0.82)$ \\
\hline$T R A D E$ & $\begin{array}{l}\text { Total trade } \\
\text { (million) }\end{array}$ & $0.17(0.26)$ & $0.32(0.37)$ & $0.11(0.11)$ & $0.07(0.10)$ \\
\hline
\end{tabular}

Note: Standard deviation in parenthesis.

Coe and Helpman (1995) elaborated on the measurement of the traderelated foreign R\&D spillover variable. $S M$ is an import-share weighted sum of $\mathrm{R} \& \mathrm{D}$ stocks of trade partners, which captures the trade composition effect of foreign $R \& D$, but not the trade intensity effect of foreign $R \& D$. As a result, for two countries with very different import intensities but identical trade composition, $S M$ would have the same value. Because of this shortcoming, Coe and Helpman (1995) proposed to use $M^{*} \log S M$ as the preferred measure of trade-related foreign $\mathrm{R} \& \mathrm{D}$ spillovers, where $M$ is the 
ratio of imports to GDP. This variable incorporates the effects of both trade intensity and trade composition. Summarizing the above considerations, we specify the following regression equation:

$$
\log T F P_{i t}=\alpha_{i t}+\alpha_{D} \log S D_{i t}+\alpha_{F} \log S F_{i t}+\alpha_{M} M_{i t} \log S M_{i t}+\varepsilon_{i t}
$$

where $\alpha_{i t}$ is a constant term that varies with country and time, and $\varepsilon_{i t}$ is an error term.

The link between TFP and R\&D in equation (1) can be derived from a standard endogenous growth model where the rate of innovation depends on R\&D input. ${ }^{11}$

In an open economy extension of such a model, both domestic R\&D and foreign R\&D matter for the rate of innovation. Coe and Helpman (1995) consider international trade as the carrier of foreign R\&D and treat foreign R\&D embodied in imported goods as complementary to domestic R\&D. Subsequent studies have made improvements in two dimensions. First, different channels of international technology diffusion have been examined, including foreign direct investment and technology licensing by multinational enterprises. ${ }^{12}$ Second, the approach has been modified to examine spillover effects in a technology catch-up process, with an emphasis on the role of human capital. ${ }^{13}$ In what follows, we incorporate this second consideration in our regression specification.

\subsection{Human Capital and Technology Catch-Up}

The economic literature has long recognized the importance of human capital and technology catch-up in the process of technology diffusion. In a classic paper, Nelson and Phelps (1966) propose a hypothesis that the rate of technology diffusion depends upon educational attainment and upon the gap between the existing technology level and the technology frontier, such that education speeds the process of technology diffusion. Using crosscountry regressions, Benhabib and Spiegel (1994) find evidence supporting the Nelson-Phelps hypothesis. A recent paper by Engelbrecht (2002), using a sample of 61 developing countries to re-estimate the models of Coe et al. (1997), identifies a positive role for human capital in the absorption of international knowledge spillovers in favour of the Nelson-Phelps hypothesis.

The endogenous growth theory provides a formulation similar to that of Nelson and Phelps (1966). ${ }^{14}$ In a closed-economy endogenous growth model, productivity growth is a function of resources devoted to technology innovation, $G T F P=g(R)$, where GTFP denotes TFP growth rate and $R$ denotes R\&D intensity. Extended to an open economy, productivity growth can come from both domestic innovation and absorption of foreign technology, GTFP $=g(R)+d\left(A^{*} / A, H, T_{F}\right)$, where the technology diffusion rate $(d)$ is a function of the gap between domestic technology level $A$ and the technology frontier $A^{*}$, level of human capital $H$, and intensity of foreign 
technology inflow $T_{F}$. Linearization of the function and using the variables we have constructed, we obtain the following regression equation: ${ }^{15}$

$$
G T F P_{i t}=\gamma_{i t}+\gamma_{D} R D L_{i t}+\gamma_{G} H_{i t} G A P_{i t}+\gamma_{F} P F L_{i t}+\gamma_{M} \Delta M_{i t} \log S M_{i t}+\eta_{i t}
$$

In equation (2), $R D L$ is $R \& D$ expenditure per worker to capture the effect of domestic technology innovation, $H$ is human capital measured by total education attainment of the population over age 15, and GAP is technology gap measured by the ratio of US TFP to country $i$ 's TFP. The interaction of $H$ and GAP captures the Nelson-Phelps hypothesis that education speeds technology catch-up. We use two variables to measure the intensity of foreign technology inflow. First, $P F L$ is the inflow of foreign patents per domestic worker, which captures the channel of foreign technology spillovers through patenting. Second, $\Delta M \log S M$ is the inflow of trade-embodying foreign $\mathrm{R} \& \mathrm{D}$, which captures the channel of foreign technology spillovers through international trade. In equation (2), $\gamma_{i t}$ is a constant that varies with country and time, and $\eta_{i t}$ is an error term.

\subsection{Determinants of Foreign Patent Inflow}

Our hypothesis is that foreign patents generate technology spillovers that benefit domestic TFP growth. If data confirm this hypothesis, we would naturally want to know what determines the inflow of foreign patents. In particular, we would like to know whether policy actions are key determinants of foreign patent inflow. In this subsection, we formulate a regression equation for this estimation.

Foreign inventors decide to patent in a country for several reasons. First, they want their inventions to be protected. Thus, other things being equal, the higher the degree of intellectual property rights protection in a country, the more foreign patents will flow to the country. We use variable IPR to capture this effect.

Second, foreign inventors' decision to patent in a country is associated with their current or potential commercial activities in the country. Other things being equal, the larger the magnitude of a country's foreign trade, the more foreign patents it may receive. To capture this effect, we use variable $T R A D E$, which is the country's total trade volume.

Third, foreign inventors file patent applications in a country because they expect to use patented technologies there. One would therefore predict that the higher the technology level of a country, the more potential use of the patented technology in that country. To capture this effect, we use variable $R T F P \equiv T F P / T_{F P}$, the ratio of TFP level relative to that of the US. ${ }^{16}$

To summarize, foreign patent inflow $(P F L)$ is a function of the recipient country's degree of IPR protection $(I P R)$, magnitude of international trade 
activity $(T R A D E)$, and level of technology $(R T F P)$. We specify the following regression equation:

$$
\log P F L_{i t}=\beta_{i t}+\beta_{1} I P R_{i t}+\beta_{T} T R A D E_{i t}+\beta_{R} R T F P_{i t}+\mu_{i t}
$$

Equation (3) is similar to those used in the literature. For example, Bosworth (1984) examines UK patent applications abroad using an equation $P_{i j}=f\left(Y_{j}, H_{j}, X_{i j}, S_{i j}, L_{j}\right)$. The patent flow from UK (country $i$ ) to country $j$ depends on country $j$ 's market size (variable $Y$ measured by GDP), development level (variable $H$ measured by GDP per capita), imports from UK (variable $X$ ), foreign direct investment from UK (variable $S$ ), and patent law (variable $L$ ). We do not use GDP as an additional variable to avoid multicollinearity; instead, we use country fixed dummies to control for the market size effect. We do not include a foreign direct investment variable because the available data are of poor quality and contain many missing values. ${ }^{17}$

\section{Results}

In this section we start by reporting results from productivity regressions and foreign patent regressions, and then use these estimates to evaluate the impact of policy changes in IPR protection and trade openness.

\subsection{Productivity Level Regressions}

Table 3 displays TFP level regressions based on equation (1). ${ }^{18}$ Regression (3.1) replicates the Coe-Helpman regression for industrial countries, with the addition of a foreign patent stock variable $(S F) .{ }^{19}$ The estimated productivity elasticities of domestic R\&D stock $(S R)$ and trade-embodying foreign $\mathrm{R} \& \mathrm{D}$ spillovers $(M \log S M)$ are 0.05 and 0.24 , respectively, compared

Table 3. TFP Level regressions, 1980-2000, Pooled data

\begin{tabular}{lcccccc}
\hline & 3.1 & 3.2 & 3.3 & 3.4 & 3.5 & 3.6 \\
& $D C$ & $D C$ & $L D C$ & $H I G H$ & $M I D D L E$ & $L O W$ \\
\hline $\log S R$ & 0.05 & & & 0.03 & & \\
& $(0.01)^{* * *}$ & & & $(0.01)^{* *}$ & & \\
$\log S D$ & & 0.06 & 0.10 & & 0.06 & 0.10 \\
& & $(0.01)^{* * *}$ & $(0.01)^{* * *}$ & & $(0.01)^{* * *}$ & $(0.02)^{* * *}$ \\
$\log \mathrm{S} F$ & 0.04 & 0.04 & 0.014 & 0.08 & 0.03 & 0.015 \\
& $(0.01)^{* * *}$ & $(0.01)^{* * *}$ & $(0.008)^{*}$ & $(0.01)^{* * *}$ & $(0.01)^{* * *}$ & $(0.008)^{*}$ \\
$M^{*} \log S M$ & 0.24 & 0.31 & 0.24 & 0.09 & 0.59 & -0.07 \\
& $(0.04)^{* * *}$ & $(0.04)^{* * *}$ & $(0.07)^{* * *}$ & $(0.03)^{* * *}$ & $(0.08)^{* * *}$ & $(0.09)$ \\
Adjusted R ${ }^{2}$ & 0.87 & 0.85 & 0.95 & 0.86 & 0.85 & 0.95 \\
Observations & 441 & 462 & 405 & 336 & 290 & 220 \\
\hline
\end{tabular}

Notes: The dependent variable is $\log$ TFP. All regressions include country dummies.

Numbers in parentheses are heteroscedasticity-adjusted standard errors. $* * *$ indicates statistical significance at the 1 per cent level, $* * 5$ per cent level, and * 10 per cent level. 
with 0.08 and 0.29 estimated by Coe and Helpman (1995). The productivity effect of foreign patents, not estimated by Coe and Helpman, shows an estimated elasticity of 0.04 .

Regression (3.2) is identical to regression (3.1) except that it uses domestic patent stock $(S D)$ instead of domestic R\&D stock $(S R)$. The results from the two regressions are similar. This provides some support for our use of domestic patent stock as an alternative to domestic R\&D stock. Regression (3.2) indicates that the effect of foreign patents is about two-thirds of the effect of domestic patents $(0.04 / 0.06=2 / 3)$ in the DC sample.

Regression (3.3) applies to our sample of developing countries. The estimated productivity elasticities of domestic patents, foreign patents, and trade-embodying foreign R\&D spillovers are 0.10, 0.014 and 0.24, respectively. Notice that the productivity effect of foreign patents is only 14 per cent of the effect of domestic patents $(0.014 / 0.10=14$ per cent $)$, much lower than the two thirds we find in the sample of developed countries.

To gain further insight, we run the regression for the three income groups. The foreign patent variable shows significant effects in all three groups. Notice that the estimated productivity effect of foreign patents is one-half the effect of domestic patents $(0.03 / 0.06=1 / 2)$ in the middle-income sample, but only 15 per cent $(0.015 / 0.10=15$ per cent $)$ in the low-income sample. Notice also that the estimated productivity effect of tradeembodying foreign technology spillovers is negative and insignificant in the low-income sample.

We should point out that the validity of the results from level regressions requires the variables to be non-stationary and cointegrated. We perform the panel data tests developed by Levin et al. (2002) and find that only half of the variables are non-stationary. ${ }^{20}$ This implies that our estimates from the level regressions may not be reliable. We thus turn to productivity growth regressions.

\subsection{Productivity Growth Regressions}

We perform TFP growth regressions for five-year intervals to better capture the technology catch-up effect. We use equation (2), which is based on an endogenous growth model of technology diffusion and incorporates the Nelson-Phelps catch-up hypothesis. ${ }^{21}$

Regression (4.1) uses the sample of developed countries. We find that domestic R\&D intensity $(R D L)$ shows a positive effect that is statistically significant at the 10 per cent level. This effect is positive at the 5 per cent statistical significance in the high-income sample in regression (4.3). We interpret this as evidence of technology innovation effects in these countries. By contrast, domestic patent intensity $(P D L)$, a proxy for domestic R\&D intensity for developing countries, shows positive but statistically insignificant effects in regression (4.2). The same result is found for the middle- and low-income samples. This finding provides support for the hypothesis that 
domestic technology innovation is not an important source for TFP growth in developing countries.

For all three income groups, we find a statistically significant effect of technology catch-up. We use total education attainment (in logarithms) to interact with the ratio of US TFP to the sample country's TFP (in logarithms, initial year in the five-year period) to estimate this effect. The results indicate that countries with a larger technology gap against the US (higher $G A P_{0}$ ) grow faster in TFP, and the speed of technology catch-up increases with the level of human capital. We view this as evidence of international technology spillovers in disembodied form.

Next we turn our attention to foreign patenting and trade. Our hypothesis is that the amount of foreign technology available for domestic absorption depends on the size of the foreign technology inflow through the patenting channel and the trade channel. We use foreign patent intensity $(P F L)$ to estimate the effect of foreign patenting. Table 4 shows that the productivity effect of foreign patenting is positive and statistically significant at the 1 per cent level in our middle- and low-income samples. By contrast, the estimated effect of foreign patenting is small and statistically insignificant in the highincome sample. Regarding the trade channel, we use variable $\Delta M \log S M$ to measure the amount of foreign $R \& D$ inflow through imported capital goods. The estimated effect on this variable is statistically significant at the 5 per cent level in our high- and middle-income samples, but is statistically insignificant in our low-income sample.

Taking the results from Table 4 as a whole, they seem to suggest a pattern. High-income countries benefit from both domestic technology innovation and foreign technology diffusion, while middle- and low-income countries benefit mainly from foreign technology spillovers. All countries enjoy technology catch-up driven by learning of foreign technology, and their

Table 4. TFP growth regressions, five-year intervals, 1980-2000

\begin{tabular}{lccccc}
\hline & 4.1 & 4.2 & 4.3 & 4.4 & 4.5 \\
& $D C$ & $L D C$ & $H I G H$ & $M I D D L E$ & $L O W$ \\
\hline$R D L$ & 0.02 & & 0.03 & & \\
& $(0.01)^{*}$ & & $(0.01)^{* *}$ & & \\
$P D L$ (thousand) & & 5.13 & & 7.77 & 1787.75 \\
& & $(6.23)$ & & $(4.95)$ & $(1233.38)$ \\
$\log H^{*} \log$ & 0.31 & 0.28 & 0.33 & 0.38 & 0.29 \\
$\left(G A P_{0}\right)$ & $(0.07)^{* * *}$ & $(0.13)^{* *}$ & $(0.07)^{* * *}$ & $(0.08)^{* * *}$ & $(0.13)^{* *}$ \\
& & & & & \\
$P F L$ (thousand) & 0.27 & 0.89 & 0.02 & 0.64 & 1.86 \\
& $(0.14)^{*}$ & $(0.43)^{*}$ & $(0.11)$ & $(0.22)^{* * *}$ & $(0.43)^{* * *}$ \\
$\Delta M^{*} \log S M$ & 0.21 & 0.23 & 0.12 & 0.21 & 0.74 \\
& $(0.07)^{* * *}$ & $(0.13)^{*}$ & $(0.05)^{* *}$ & $(0.08)^{* *}$ & $(0.48)$ \\
Adjusted $\mathrm{R}^{2}$ & 0.50 & 0.21 & 0.47 & 0.50 & 0.20 \\
Observations & 84 & 90 & 64 & 58 & 52 \\
\hline
\end{tabular}

Notes: The dependent variable is GTFP. All regressions include country and time dummies. 
human capital level determines the rate at which they learn from foreign technology. Middle-income countries seem to enjoy technology spillovers from both foreign patents and imported capital goods. For high-income countries, imported capital goods generate technology spillovers but foreign patents do not seem to show much of a technology spillover effect. By contrast, for low-income countries, foreign patents generate significant technology spillover effects but imported capital goods do not. We should point out that these results are only suggestive and should be interpreted with caution. ${ }^{22}$

\subsection{Foreign Patent Regressions}

One robust result from the previous subsection is that the inflow of foreign patents has a positive effect on TFP growth in middle- and low-income countries. We now use equation (3) to estimate the determinants of foreign patent inflow.

Table 5 reports results from six regressions that use different subsets of the sample. The dependent variable is the number of foreign patent applications per thousand workers in logarithms $(\log P F L)$. Notice first that IPR protection $(I P R)$ has a positive effect at the 1 per cent statistical significance in all regressions. The quantitative effects of IPR improvement are quite large; an increase of IPR index by one level (about one standard deviation) would increase the number of foreign patents per thousand workers by 8.42 in the high-income sample, 2.27 in the middle-income sample, and 2.66 in the low-income sample.

Table 5 shows that the number of foreign patents per thousand workers $(\log P F L)$ depends also on the volume of foreign trade $(T R A D E)$ and the technology level relative the United States $(R T F P)$. Notice however that the effects are strong in middle- and low-income countries but weak in highincome countries. Graphically, we see in Figure 2 that there is a clear positive relationship between the number of foreign patents per thousand workers and real GDP per capita in low- and middle-income countries, but

Table 5. Determinants of foreign patent inflow, 1980-2000

\begin{tabular}{lcccccc}
\hline & 5.1 & 5.2 & 5.3 & 5.4 & 5.5 & 5.6 \\
& $A L L$ & $D C$ & $L D C$ & $H I G H$ & $M I D D L E$ & $L O W$ \\
\hline IPR & 1.42 & 2.40 & 0.59 & 2.13 & 0.82 & 0.98 \\
& $(0.11)^{* * *}$ & $(0.17)^{* * *}$ & $(0.13)^{* * *}$ & $(0.20)^{* * *}$ & $(0.19)^{* * *}$ & $(0.24)^{* * *}$ \\
TRADE & 1.23 & 0.14 & 5.27 & 0.13 & 5.63 & 4.57 \\
& $(0.31)^{* * *}$ & $(0.20)$ & $(0.63)^{* * *}$ & $(0.19)$ & $(1.04)^{* * *}$ & $(0.73)^{* * *}$ \\
RTFP & 4.49 & 3.39 & 2.54 & 1.19 & 4.00 & 4.61 \\
& $(0.87)^{* * *}$ & $(0.89)^{* * *}$ & $(0.76)^{* * *}$ & $(1.07)$ & $(0.77)^{* * *}$ & $(1.45)^{* * *}$ \\
Adjusted $\mathrm{R}^{2}$ & 0.89 & 0.67 & 0.81 & 0.70 & 0.80 & 0.65 \\
Observations & 1004 & 462 & 542 & 357 & 311 & 336 \\
\hline
\end{tabular}

Notes: The dependent variable is $\log P F L$. All regressions include country dummies. 
no such relationship exists among the high-income countries. The reason for this is yet to be explored. ${ }^{23}$

\subsection{Policy Implications}

We now use the estimates from our productivity regressions and foreign patent regressions to assess the impact of policy changes. We consider two policies, one being IPR protection, and the other being trade openness. We will focus on middle- and low-income countries since our results show that foreign patents generate positive technology spillovers in middle- and lowincome countries but not in high-income countries.

First consider an improvement in IPR protection by one level. This is approximately equivalent to Indonesia (0.64) raising its IPR level to that of Colombia (1.57), for Colombia to raise IPR to that of Greece (2.51), for Greece to raise IPR to that of New Zealand (3.48), or for New Zealand to raise IPR to that of the United States (4.55). In the middle-income sample, an increase in IPR by one level implies an increase in the number of foreign patents per thousand workers by 2.27 (regression 5.5). This increase in foreign patents implies an increase in TFP growth rate by 0.15 percentage points (based on regression 4.4). Given that TFP of the middle-income countries grows at an average rate of 0.9 percentage points (Table 2), a onelevel IPR improvement would contribute to TFP growth by 17 per cent $(0.15 / 0.9)$. Following the same procedure, we find that a one-level IPR improvement would increase the number of foreign patents per thousand workers by 2.66 in the low-income countries, implying an increase in their average TFP growth rate by 0.49 percentage points and contributing to their TFP growth by about 55 per cent $(0.49 / 0.89)$. We summarize the above results in the first two columns of Table 6.

Next we consider trade policy. For comparison with the IPR policy effects discussed above, consider an increase in trade openness that leads to an increase in trade volume by 40 per cent. ${ }^{24}$ The average trade volume of the

Table 6. Policy implications

\begin{tabular}{lcccccc}
\hline & $\begin{array}{c}\text { MIDDLE } \\
\text { IPR }\end{array}$ & $\begin{array}{c}\text { LOW } \\
\text { IPR }\end{array}$ & $\begin{array}{c}\text { MIDDLE } \\
\text { TRADE }\end{array}$ & $\begin{array}{c}\text { MIDDLE } \\
\text { TRADE }\end{array}$ & $\begin{array}{c}\text { LOW } \\
\text { TRADE }\end{array}$ & $\begin{array}{c}\text { LOW } \\
\text { TRADE }\end{array}$ \\
\hline Policy change & +1.00 & +1.00 & $+40 \%$ & $+40 \%$ & $+40 \%$ & $+40 \%$ \\
$\Delta P F L$ & 2.27 & 2.66 & 1.28 & & 1.14 & \\
$\Delta M * \log S M$ & & & & 0.0025 & & 0.0004 \\
GTFP (\%) & 0.15 & 0.49 & 0.08 & 0.05 & 0.21 & 0.03 \\
$\begin{array}{l}\text { Contribution } \\
\text { to GTFP }\end{array}$ & $17 \%$ & $55 \%$ & $9 \%$ & $6 \%$ & $24 \%$ & $3 \%$ \\
\hline
\end{tabular}


middle-income countries is 0.11 million dollars, so a 40 per cent increase implies an increase in trade volume by 44 thousand dollars. According to regression (5.5), this implies an increase in the number of foreign patents per thousand workers by 1.28. In regression (4.4), this increase in foreign patents drives up TFP growth rate by 0.08 percentage points. Thus the contribution to TFP growth is about 9 per cent. Following the same procedure, we find that a 40 per cent increase in trade volume in the lowincome countries would increase the number of foreign patents per thousand workers by 1.14 (regression 5.6), implying an increase in average TFP growth rate by 0.21 percentage points (regression 4.5) and contributing to TFP growth by about 24 per cent.

The trade effect computed above is only the effect of trade openness in attracting more foreign patents. In our model, trade openness also improves TFP growth by increasing the amount of technology spillovers embodied in imported capital goods. To estimate the effect of trade openness on TFP growth though this spillover channel, we first estimate how TRADE affects $\Delta M \log S M$, and then use the results with regressions (4.4) and (4.5) to estimate the effect of TRADE on TFP growth. ${ }^{25}$ According to our estimation, if trade openness causes trade volume to increase by 40 per cent, it implies an increase in $\Delta M \log S M$ by 0.0025 in the middle-income sample and 0.0004 in the low-income sample, which in turn implies an increase in TFP growth by 0.05 percentage points $(6$ per cent contribution to TFP growth) in the middle-income sample and 0.03 percentage points ( 3 per cent contribution to TFP growth) in the low-income sample. Thus, the total effect of a 40 per cent increase in trade volume is to increase TFP growth rate by 0.13 percentage points in the middle-income sample ( 15 per cent contribution to TFP) and by 0.24 percentage points in the low-income sample (27 per cent contribution to TFP). We summarize the above results in the last four columns of Table 6 .

The above experiments highlight the significance of IPR policy and trade policy in stimulating foreign technology diffusion and productivity growth in middle- and low-income countries. An improvement in IPR creates an environment that attracts more foreign patents; the resulting technology spillovers bring large productivity gains to middle-income countries and even larger gains to low-income countries. An increase in trade openness stimulates foreign patent inflow and also results in more imported capital goods that embody foreign technology, leading to beneficial technology spillover effects in both middle- and low-income countries. The trade effect on foreign patents is relatively small for the middle-income sample and the trade effect through imported capital goods is relatively small for the lowincome sample. Overall, a change in IPR policy seems to bring more productivity gains than a comparable change in trade policy. Note that our computation does not take into account the effects of trade openness and IPR protection on disembodied technology spillovers and possibly other factors. 


\section{Summary and Conclusions}

In this paper we investigated the effects of international technology diffusion using a sample of 48 countries for the period 1980 to 2000. We considered international trade and foreign patenting as two channels for technology spillovers across national borders, taking into account technology diffused in disembodied form in a technology catch-up process. We examined the policy implications of intellectual property rights protection and trade openness in relation to international technology diffusion.

By splitting the sample into three income groups, we examined the sources of productivity growth in each group. We found that domestic technology is a significant source for productivity growth in the high-income sample, but not so much in the middle- and low-income samples. All countries benefit from foreign technology spillovers, but there are differences in the channels they rely on. We found that foreign patents generate significant technology spillovers in middle- and low-income countries, but less in high-income countries. By contrast, foreign technology embodied in imported capital goods has a significant productivity effect in our high- and middle-income samples, but not in our low-income sample. All samples show a strong technology catch-up effect, which we interpret as reflecting absorption of foreign technology in disembodied form. Finally, an increase in human capital increases the rate of technology catch-up, supporting the hypothesis of Nelson and Phelps (1966) on the role of human capital in technology diffusion.

We assessed the effects of trade and IPR policies using estimates from productivity regressions and foreign patent regressions. In our framework, trade openness impacts productivity by bringing in capital goods that embody foreign technology, and by stimulating inflow of foreign patents. We found that the technology spillover effect of trade openness from attracting foreign patents is larger than that from enhancing capital goods imports in both the middle- and low-income samples, and is particularly significant in the low-income sample. An improvement in IPR protection has a large productivity effect as well. In our experiment with the middleincome sample, a 40 per cent increase in IPR protection would increase TFP growth rate by 0.15 percentage points, and a 40 per cent increase in foreign trade would increase TFP growth by 0.13 percentage points. The effects are larger in the low-income sample, with the two estimates being 0.49 and 0.24 percentage points.

Our results suggest that countries at different development stages benefit from different sources and different forms of international technology spillovers, and that economic policies play a significant role in determining both the amount and form of foreign technology spillovers. More research is needed to identify the patterns of international technology diffusion in economic development and to provide policy recommendations tailored for countries at different development stages. 


\section{Appendix}

In this appendix we provide information on data sources and construction. Patent data are published by the World Intellectual Property Organization (WIPO). Data from recent years are available from the WIPO website, while data for earlier years are published in Industrial Property Statistics. We use data on the number of patent applications by residents and by nonresidents. Following Eaton and Kortum (1996), we translate 4.9 Japanese domestic patent applications into the equivalent of one application elsewhere. Inconsistencies found in the WIPO data for OECD countries are corrected using the Basic Science and Technology Statistics published by the OECD, which contains more accurate data for recent years. Patent flow data are largely complete for the 48 countries in our sample; a few missing data are interpolated using neighbouring data. We construct beginning-ofyear patent stocks from patent flows using the perpetual inventory model $S_{t}=(1-\delta) S_{t-1}+P_{t-1}$, where $\delta$ is the depreciation rate, which is assumed to be 15 per cent. $^{26}$ The initial value for patent stock, $S_{0}$, is calculated, following a standard procedure in the literature, as $S_{0}=P_{0} /(g+\delta)$, where $P_{0}$ is the patent flow in 1963 and $g$ is the average growth rate of patent flows of the first ten years.

Penn World Table 6.1 (PWT 6.1) is another data source. We define total factor productivity (TFP) as $Y /\left[K^{\alpha} L^{(1-\alpha)}\right]$, where $Y$ is real GDP in 1996 international prices, $K$ is accumulated investment in 1996 international prices, $L$ is labour force, and $\alpha$ is set to equal 0.4 . We use the perpetual inventory method to compute capital stocks from investment data; the depreciation rate is 10 per cent. Variables $R G D P L, G A P$, and TRADE come directly from PWT 6.1. Variable $H$ uses data constructed and updated by Barro and Lee (1996). Variable IPR uses data constructed and updated by Ginarte and Park (1997).

We use R\&D data from Coe and Helpman (1995) for the period $1980-$ 1990, and update the data using Source OECD for the period 1991-2000. We interpolate a few missing data using neighbouring data. The CoeHelpman data are in 1985 prices and the recent data are in 1995 prices. We use GDP deflators from OECD to convert all values to 1995. Capital goods imports are imports of machinery and transport equipment (SITC 7). Bilateral data on imported capital goods are available from the United Nations annual publication Bulletin of Statistics on World Trade in Engineering Products for the period 1980-1990. However, there are no available data of bilateral data on imported capital goods that extend to year 2000, so we use exports of capital goods by five major industrial countries (US, UK, Japan, Germany, and France) to measure the capital goods imports of the countries in our sample. This practice applies to the entire sample period including 1980-1990. 


\section{Notes}

The Authors thank three anonymous referees for useful comments and suggestions, and Walter Park for providing valuable comments on an earlier draft and updated data on the IPR index. Bin Xu acknowledges the research support from Darden School of the University of Virginia where he visited in spring 2004 and worked on the final version of the paper.

${ }^{1}$ Keller (2004) provides a survey of the literature on international technology diffusion.

${ }^{2}$ A number of papers investigate technology spillovers from industrial countries to developing countries (e.g. Coe et al., 1997; Bayoumi et al., 1999). Our paper investigates if the spillover channels of developing countries differ from those of industrial countries.

${ }^{3}$ Previous studies that specify one channel may overestimate the importance of the channel in international technology diffusion. For example, Coe and Helpman (1995) estimate an equation with international trade as the sole channel of international R\&D spillovers. Keller (1998) finds, however, that the international R\&D spillovers identified in Coe and Helpman (1995) are not related to international trade per se, but are a result of various unspecified spillover channels.

${ }^{4}$ Still, the patent data is available only for 26 LDCs in addition to 22 DCs, which limits our sample to 48 countries.

${ }^{5}$ One reason for Iceland (128) to be an outlier in Figure 2 is that Iceland's IPR protection is significantly weaker than countries at the same development stage. Iceland has an IPR index of 2.23, much lower than 3.71, the average IPR index for high-income countries.

${ }^{6}$ The United Kingdom is at the margin of the high-income group and the middle-income group and we classify it as a high-income country because it is one of the major technologyinnovating countries.

${ }^{7}$ For developing countries, total education attainment in population over age 15 is a better measure than total education attainment in population over age 25 . We thank a referee for his/her recommendation of this measure.

${ }^{8}$ See Xu and Wang (1999) for empirical evidence on capital goods being the main carrier of foreign technology spillovers embodied in trade flows.

${ }^{9}$ In Coe et al. (1997), variable $M$ is the GDP share of imported capital goods from 22 industrialized countries. We do not have bilateral data on imported capital goods for all developed countries that extend to year 2000, but we construct the data for five major industrial countries from the data on their exports of capital goods.

${ }^{10}$ Domestic R\&D stock and domestic patent stock are highly correlated. In our sample of developed countries, the correlation is 0.91 .

${ }^{11}$ See Coe and Helpman (1995: section 2) for a discussion.

${ }^{12}$ For example, Hejazi and Safarian (1999) and van Pottelsberghe de la Potterie and Lichtenberg (2001) investigated R\&D spillovers through foreign direct investment. Xu (2000) estimated R\&D spillovers through technology licensing of multinational enterprises.

13 Engelbrecht (1997) points out the need to consider the role of human capital in the CoeHelpman estimation. Engelbrecht (2002) shows further the importance of considering the role of human capital and technology catch-up in international technology diffusion.

${ }^{14}$ See Barro and Sala-i-Martin (1997) for detail of the model.

${ }^{15}$ Benhabib and Spiegel (2002) have explored the nonlinearity of this equation.

${ }^{16}$ Note that $R T F P \equiv \mathrm{TFP} / \mathrm{TFP}_{\mathrm{US}}$ is the reciprocal of $G A P \equiv \mathrm{TFP}_{\mathrm{US}} / \mathrm{TFP}$. We define a different variable to avoid confusion.

${ }^{17}$ Eaton and Kortum (1996) and Park (2000) are two recent studies that estimate bilateral patent flows. Eaton and Kortum (1996) estimate an equation in which patent flow per source country worker depends on the sourcing country's R\&D intensity, the recipient country's human capital, import-GDP ratio, IPR protection, and distance between the two countries. Park (2000) estimates a similar equation in which patent flow per source country worker depends on the source country's number of scientists and engineers per 10,000 workers, the 
recipient country's GDP, IPR protection, imitative capacity (a weighted average of R\&DGDP ratio and scientists and engineers per 10,000 workers), and patent filing costs.

${ }^{18}$ Like Coe and Helpman (1995), we do not include time dummies in the regressions. Including time dummies would render the effects of some of the variables unidentifiable because the variables have a time trend.

${ }^{19}$ Our sample period is $1980-2000$ while the sample period of Coe and Helpman (1995) is $1971-1990$.

${ }^{20}$ In the DC sample, the Levin - Lin - Chu test does not reject that $\log T F P$ and $\log S F$ are nonstationary, but rejects that $\log S D$ and $M \log S M$ are non-stationary. In the LDC sample, the Levin - Lin-Chu test does not reject that $\log S D$ and $\log S F$ are non-stationary, but rejects that $\log T F P$ and $M \log S M$ are non-stationary.

${ }^{21}$ Regressions with a simple time difference of equation (1) yield poor results.

22 One potential bias comes from endogeneity of the explanatory variables. We do not deal with this problem because of lack of instrumental variables. Multicollinearity is less an issue since the correlations between explanatory variables are quite low. For example, in the highincome sample, the correlations are -0.15 between $R D L$ and $\log H^{*} \log G A P, 0.36$ between $R D L$ and $P F L,-0.09$ between $R D L$ and $\triangle M \log S M, 0.17$ between $\log H^{*} \log G A P$ and $P F L$, zero between $\log H^{*} \log G A P$ and $\triangle M \log S M$, and -0.11 between $P F L$ and $\triangle M \log S M$.

${ }^{23}$ Note that we do not include time dummies in the reported regressions. Including them would change the signs of some estimated effects. IPR would remain positive and statistically significant in all regressions except for that of the middle-income sample, and TRADE would show a negative effect in the high-income sample.

${ }^{24}$ We choose a 40 per cent increase in TRADE because a one-level increase in IPR implies an increase of 36 per cent in $I P R$ for the middle-income sample and an increase of 44 per cent in $I P R$ for the low-income sample.

${ }^{25}$ In the regressions of $\triangle M \log S M$ against TRADE, the estimated coefficients on TRADE are 0.057 (standard error 0.018 ) for the middle-income sample and 0.015 (standard error 0.008) for the low-income sample.

${ }^{26}$ This depreciation rate has been commonly chosen in constructing patent stocks. See Adams (1997), for example.

\section{References}

Adams, J. D. (1997) Technology, trade, and wages. NBER Working Paper No. 5940.

Barro, R. J. and Lee, J. (1996) International measures of schooling years and schooling quality, American Economic Review, 86, pp. 218-223.

Barro, R. J. and Sala-i-Martin, X (1997) Technology diffusion, convergence, and growth, Journal of Economic Growth, 2, pp. 1-26.

Bayoumi, T., Coe, D. T. and Helpman, E. (1999) R\&D spillovers and global growth, Journal of International Economics, 47, pp. 399-428.

Benhabib, J. and Spiegel, M. (1994) The roles of human capital in economic development: evidence from aggregate cross-country data, Journal of Monetary Economics, 34, pp. $143-$ 173.

Benhabib, J. and Spiegel, M. (2002) Human capital and technology diffusion. Federal Reserve Bank of San Francisco Working Paper 03-02.

Bosworth, D. L. (1984) Foreign patent flows to and from the United Kingdom, Research Policy, 13, pp. $115-124$.

Coe, D. T. and Helpman, E. (1995) International R\&D spillovers, European Economic Review, 39, pp. 859-887.

Coe, D. T., Helpman, E. and Hoffmaister, A. W. (1997) North-South R\&D spillovers, Economic Journal, 107, pp. 134-149.

Eaton, J. and Kortum, S. (1996) Trade in ideas: patenting and productivity in the OECD, Journal of International Economics, 40, pp. 251-278. 
Engelbrecht, H.-J. (1997) International R\&D spillovers, human capital and productivity in OECD economies: an empirical investigation, European Economic Review, 41, pp. 14791488.

Engelbrecht, H.-J. (2002) Human capital and international knowledge spillovers in TFP growth of a sample of developing countries: an exploration of alternative approaches, Applied Economics, 34, pp. $831-841$.

Ginarte, J. C. and Park, W. G. (1997) Determinants of patent rights: across-national study, Research Policy, 26, pp. 283-301.

Hejazi, W. and Safarian, E. (1999) Trade, foreign direct investment, and R\&D spillovers, Journal of International Business Studies, 30, pp. 491-511.

Keller, W. (1998) Are international R\&D spillovers trade-related? Analyzing spillovers among randomly matched trade partners, European Economic Review, 42, pp. 1469-1481.

Keller, W. (2004) International technology diffusion, Journal of Economic Literature, forthcoming.

Levin, A., Lin, C. and Chu, C. (2002) Unit root tests in panel data: asymptotic and finite sample properties, Journal of Econometrics, 108, pp. 1-24.

Nelson, R. R. and Phelps, E. S. (1966) Investment in humans, technology diffusion, and economic growth, American Economic Review, 56, pp. 69-75.

Park, W. G. (2000) International patenting, patent rights, and technology gaps. Mimeo, American University.

van Pottelsberghe de la Potterie, B. and Lichtenberg, F. (2001) Does foreign direct investment transfer technology across boarders?, The Review of Economics and Statistics, 83, pp. 490497.

$\mathrm{Xu}, \mathrm{B}$. (2000) Multinational enterprises, technology diffusion, and host country productivity growth, Journal of Development Economics, 62, pp. 477-493.

$\mathrm{Xu}, \mathrm{B}$. and Wang, J. (1999) Capital goods trade and R\&D spillovers in the OECD, Canadian Journal of Economics, 32, pp. 1258-74. 